\title{
A scientific note on DNA fragmentation rates in sperm collected from drones and spermathecae of queens of different age, with possible implications on the scattered brood phenomenon
}

\author{
Grzegorz BorsuK $^{1}$, Monika KozŁowsKA ${ }^{2}$, Marcin AnUSIEWIIz $^{2}$, Krzysztof OlszewskI ${ }^{1}$ \\ ${ }^{1}$ Institute of Biological Basis of Animal Production, Faculty of Biology, Animal Sciences and Bioeconomy, University of Life \\ Sciences, Akademicka 13, 20-950, Lublin, Poland \\ ${ }^{2}$ Department of Botany and Mycology, Institute of Biology and Biochemistry, Faculty of Biology and Biotechnology, Maria Curie- \\ Skłodowska University, Akademicka 19, 20-033, Lublin, Poland
}

Received 2 May 2018 - Revised 26 July 2018 - Accepted 6 September 2018

\section{DNA fragmentation / scattered brood / drone / bee queen / sperm / semen quality / chromatin dispersion}

Social insects have developed a polyandrous mating system characterised by the highest level of organisation among bees (Cole 1983; Moritz 1983; Palmer and Oldroyd 2000; Kraus et al. 2004). The bee queen copulates with many drones (Tryasko 1951; Morizt et al. 1996; Neumann and Moritz 2000). During the mating flight, a comet of drones follows the queen and the drones compete to be able to copulate with her. However, queens are preferentially inseminated by drones of their own race (Kerr and Bueno 1970; Koeniger et al. 1989). A successful copulation depends on the queens because they make the choice, opening their sting chamber to allow a male to insert its genitalia (Winston 1991; Strassmann 2001).

After copulation, lateral oviducts contain from 10 to 150 million spermatozoa (Ruttner and Koeniger 1971). After 24 h, 3-7 million spermatozoa reach the spermatheca (Ruttner and Koeniger 1971). Sperm transport into the spermatheca is facilitated by spermatozoa movement (Bishop 1920), passive transport forced by ovarian and abdominal muscle contraction (Berlepsch 1873), spermathecal pump (Bresslau 1905), and a combination of sperm locomotion with passive transport by the reproductive system of the bee queen (Ruttner 1956).

The semen of many drones is mixed in the reproductive tract of the bee queen and the queen

Corresponding author: G. Borsuk, grzegorz.borsuk@up.lublin.pl

Manuscript editor: Klaus Hartfelder successively fertilises the eggs in a number of batches (Woyke 1963a; Borsuk et al. 2011).

The aim of this study was to determine the occurrence of sperm DNA fragmentation in drone sperm and estimate the number of such cells in queen's spermatheca.

Drone breeding was conducted in June 2017 using drones originating from five Apis mellifera carnica queens. To obtain drones of the same age, the queen was caged for 2 days on a single drone comb using a queen excluder. Then the queen was released, and the comb remained caged to protect it from further oviposition. On post-oviposition day 23 , the comb was transferred to a $34{ }^{\circ} \mathrm{C}$ incubator to induce drone emergence. The emerging drones were individually marked using queen bee marking numbers. Then, 50 drones from 5 bee queens were placed in 5 separate colonies. The outlets were barred with queen excluders to prevent the drones from leaving the colonies. On day 14 after emergence, the drones were captured and their semen was collected using a $1-\mu \mathrm{L}$ calibrated micropipette. Semen samples were used for DNA fragmentation analysis.

One-, two-, three- and four-year-old naturally inseminated A. m. carnica queens were chose in September 2017 from bee colonies kept in the apiary of the University of Life Sciences in Lublin (51 $\left.{ }^{\circ} 13^{\prime} \mathrm{N}, 22^{\circ} 38^{\prime} \mathrm{E}\right)$. Ten honeybee queens were chose in each age group. They were anaesthetised with $\mathrm{CO}_{2}$, the spermathecae were dissected, and sperm was sampled for DNA fragmentation analysis. 
To quantify the sperm DNA fragmentation, we used the Sperm DNA Fragmentation (SDF) test from Halosperm ${ }^{\circledR}$ (Halotech DNA SL, ISO 13485). This assay is based on sperm chromatin dispersion. The sperm samples were diluted with a $400 \times$ PBS solution and microscopic slide were prepared and stained in accordance with the manufacturer's instructions.

We prepared ten sperm samples from drones originating from five colonies. In total, 50 samples were collected from the drones. Ten sperm samples were collected from the 1-, 2-, 3- and 4-year-old queens, i.e. in total, 40 samples were collected from all queens.

Then we counted the sperm cells in five fields of vision from each sample using a Nikon Eclipse Ni bright-field microscope at $\times 400$ magnification. In each field of vision, we counted ten sperm cells with fragmented and degraded DNA and normal spermatozoa. We calculated the percentage of sperm with fragmented DNA.

Statistical analysis was performed using SAS software version 9.5 (Statistical Analysis System Institute, Cary, NC). The multivariate analysis of variance showed no significant effect of the colony or queens' age $(F=28.61 p=0.2284)$; therefore, we carried out comparisons between the sperm collected from the drones and the sperm sampled from the spermatheca of the 1-, 2-, 3- and 4-year-old bee queens were performed with one-way ANOVA, Tukey test. Percentage data were arcsine-transformed (Sokal and Rohlf 1981).

In total, we analysed 2500 sperm cells collected from the drones and 2000 sperm cells sampled from the spermathecae of the bee queens. The analysis revealed the significantly ( $F=25.89 ; p=0.0000)$ highest percentage of sperm DNA fragmentation (SDF) in the drones $(14.46 \%)$ and a slightly lower proportion in the queens (1-year-old, 10. 44\%; 2-year-old, 10.89; 3-yearold, 8.82; 4-year-old, 7.20 mean 9.33\%) (Figure 1). There were significantly higher DNA fragmentation (SDF) rates in sperm collected directly from the drones, in comparison with sperm sampled from all queens (Figure 1). There was also a significant difference in sperm DNA fragmentation (SDF) between the 1- and 2year-old queens and the 4-year-old queens (Figure 1). This indicates that sperm in queens' spermathecae is well nourished and aerated and storage does not increase the proportion of sperm DNA fragmentation (SDF). Similar conclusions were formulated by Collins et al. (2004), Klenk et al. (2004), Baer et al. (2009), Poland et al. (2011), Holman et al. (2011) and Wegener et al. (2013). They found that long-term storage of spermatozoa by social insects maintains the high molecular and physiological quality of the cells.

This method turned out to be applicable in beekeeping for detection of sperm DNA fragmentation (SDF) (Borsuk et al. 2018). The higher percentage of sperm DNA fragmentation (SDF) in the drones than in the queens (Figure 1) can be explained by the fact that sperm cells with DNA fragmentation (SDF) reach the spermatheca together with sperm with non-fragmented DNA.

Some sperm with fragmented and non-fragmented DNA is expelled from the queen's body after copulation (Koeniger 1986). As many as $10 \%$ out of the $14 \%$ of sperm with fragmented DNA (SDF) detected in the

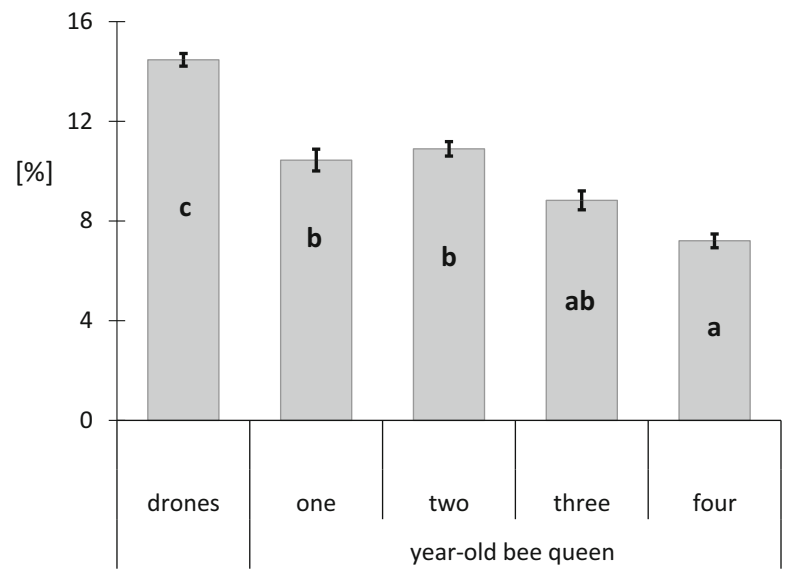

Figure 1 Percentage of sperm DNA fragmentation. Bars indicate standard deviation. a-c The different small letters indicate differences between sperm from drones and 1-, 2-, 3- and 4-year-old bee queens at $p<0.01$ (ANOVA, Tukey test). 
drones reach the spermatheca (Figure 1). They are morphologically and physiologically normal sperm cells with damaged DNA (Benchaib et al. 2003; Osman et al. 2015; Simon et al. 2017). When the queen begins to lay eggs, spermatozoa leave the spermatheca. In the first 2 years of laying eggs, sperm cells with DNA fragmentation (SDF) probably lose the competition for leaving the spermatheca with the strongest sperm and remain in the spermatheca until it contains lower sperm amounts. Only then are they able to compete with other spermatozoa for priority in fertilisation of eggs. If not, the lower percentage of sperm with SDF in old queens could even indicate that they may have died earlier than normal sperm. That is why we observed a reduction of sperm cell DNA fragmentation (SDF) in the 3- and 4year-old bee queens (Figure 1).

Currently, the following causes of the scattered brood phenomenon are suggested:

- the queens' age and failing old queen (Sammataro and Avitabile 1998; Jabde 2005; Head 2010);

- poor queen quality; the failure is due to an unfortunate mating flight taken by the queen (Koeniger et al. 2014);

- irregular deposition of eggs by the queen (Woyke 1976);

- bacterial brood diseases (European Foulbrood, American Foulbrood), which prevent rearing the brood to the adult stage (Woyke 1976);

- a high degree of inbreeding; this causes homozygosis of the sex locus (Mackensen 1951; Woyke 1962; Koeniger et al. 2014).

Eggs fertilised by sperm cells with DNA fragmentation (SDF) do not develop normally and are probably eaten by bees, likewise eggs with diploid drones (Woyke 1963b, c). Empty cells remain after the eggs have been eaten by bees; therefore, scattered brood is observed more frequently in older queens, failing old queen, or poor queen quality (Sammataro and Avitabile 1998; Jabde 2005; Head 2010, Koeniger et al. 2014). The sperm supply in the spermatheca declines with the queen's age (Akyol et al. 2008; Gregorc et al. 2008; AlLawati et al. 2009), which results in irregularities in egg deposition (Woyke 1976) and emergence of scattered brood. Harbo (1979) demonstrated that the queen uses always the same sperm volume for egg fertilisation; accordingly, many spermatozoa are used in young queens and very few in old queens. In the present investigations, the 3- and 4-year-old queens had fewer spermatozoa with DNA fragmentation (SDF) (Figure 1), which were not the first to die in the spermatheca, due to their lower number. Therefore, it is highly probable that they fertilised the eggs deposited by the queen, which were then eaten by the bees and scattered brood developed.

Our investigations expand the knowledge of the phenomenon of scattered brood in honeybee colonies with older queens.

\section{AUTHOR'S CONTRIBUTIONS}

GB conceived this research and designed experiments; MK MA performed experiments and analysis; GB KO wrote the paper and participated in the revisions of it.

\section{OPEN ACCESS}

This article is distributed under the terms of the Creative Commons Attribution 4.0 International License (http://creativecommons.org/licenses/by/4.0/), which permits unrestricted use, distribution, and reproduction in any medium, provided you give appropriate credit to the original author(s) and the source, provide a link to the Creative Commons license, and indicate if changes were made.

Une note scientifique sur les taux de fragmentation de l'ADN dans les spermatozoïdes prélevés chez des mâles et des spermathèques de reines d'âge différent, avec des implications possibles sur le phénomène de couvain dispersé

Eine wissenschaftliche Notiz über DNAFragmentierungsraten im Sperma, das von Drohnen und aus der Spermatheka von Königinnen unterschiedlichen Alters gewonnen wurde, und mögliche Implikationen für das Lückenbrutphänomen

\section{REFERENCES}

Akyol, E., Yeninar, H., Kaftanoglu, O. (2008) Live Weight of Queen Honey Bees (Apis mellifera L.) Predicts Reproductive Characteristics. J. Kansas Entomol. Soc. 81, 92-100

Al-Lawati, H., Kamp, G., Bienefeld, K. (2009) Characteristics of the spermathecal contents of old and young honeybee queens. J. Insect Physiol. 55, 116-21

Baer, B., Heazlewood, J. L., Taylor, N. L., Eubel, H., Millar, A. H. (2009) The seminal fluid proteome of the honeybee Apis mellifera. Proteomics 9, 2085-2097

Benchaib, M., Braun, V., Lornage, J., Hadj, S., Salle, B., Lejeune, H., Guérin, J. F. (2003) Sperm DNA fragmentation decreases 
the pregnancy rate in an assisted reproductive technique. Hum. Reprod. 18, 1023-1028

Berlepsch, A. V. (1873) Die Biene und ihre Zucht mit beweglichen Waben in Gegenden ohne Spätsommertracht. G. Schneider, Mannheim

Bishop, G. H. (1920) Fertilization in the honeybee. J. Exp. Zool. 3, 225-286

Borsuk, G., Olszewski, K., Strachecka, A., Paleolog, J., Gagoś, M. (2011) Microscopic image of honeybee drone spermatozoa in three diluents. J. Apic. Sci. 55, 73-80

Borsuk, G., Kozłowska, M., Anusiewicz, M., Paleolog, J. (2018) Nosema ceranae changes semen characteristics and damages sperm DNA in honeybee drones. ISJ-Invert. Surviv. J. 15, 197-202

Bresslau, E. (1905) Der Samenblasengang der Bienenkönigin. Zool. Anz. 29, 299-325.

Cole, B. J. (1983) Assembly of mangrove ant communities: colonization abilities. J. Anim. Ecol. 52, 349-355

Collins, A. M., Williams, V., Evans, J. D. (2004) Sperm storage and antioxidative enzyme expression in the honey bee, Apis mellifera . Insect Mol. Biol. 13, 141-146

Gregorc, A., Lokar, V., Smodis, M. I. (2008) Testing of the isolation of the Rog-Ponikve mating station for Carniolan (Apis mellifera carnica) honey bee queens. J. Apic. Res. 47, 137140

Harbo, J. R. (1979) The rate of depletion of spermatozoa in the queen honey bee spermatheca. J. Apic. Res. 18, 204-207

Head, V. (2010) Keeping Bees. Arcturus Publishing Limited

Holman, L., Steurup, M., Trontti, K., Boomsma, J. J. (2011) Random sperm use and genetic effects on worker caste fate in Atta colombica leaf-cutting ants. Mol. Ecol. 20, 5092-5102

Jabde, P.V. (2005) Text Book of Applied Zoology. Discovery Publishing House New Delhi

Kerr, W. E., Bueno, D. (1970) Natural crossing between Apis mellifera adansonii and Apis mellifera ligustica. Evolution 24, 145-155

Klenk, M., Koeniger, G., Koeniger, N., Fasold, H. (2004) Proteins in spermathecal gland secretion and spermathecal fluid and the properties of a $29 \mathrm{kDa}$ protein in queens of Apis mellifera. Apidologie 35, 371-381

Koeniger, G. (1986) Reproduction and mating behaviour, in: Rinderer T. E. (ed.) Bee Genetics and Breeding. Academic Press, New York

Koeniger, G., Koeniger, N., Pechhacker, H., Ruttner, F., Berg, S. (1989) Assortative mating in a mixed population of European honeybees Apis mellifera ligustica and Apis mellifera carnica. Insect. Soc. 36, 129-138

Koeniger, G., Koeniger, N., Ellis, J., Connor, L. (2014) Mating Biology of Honey Bees (Apis mellifera), 1. , Kalamazoo: Wicwas Press

Kraus, F. B., Neumann, P., van Praagh, J., Moritz, R. F. A. (2004) Sperm limitation and the evolution of extreme polyandry in honeybees (Apis mellifera L.). Behav. Ecol. Sociobiol. 55 (5): 494-501. https://doi.org/10.1007/s00265-003-0706-0
Mackensen, O. (1951) Viability and sex determination in the honey bee (Apis mellifera L.) Genetics 36, 500-509

Moritz, R. F. A. (1983) Homogeneous mixing of honeybee semen by centrifugation. J. Apic. Res. 22, 249-255

Moritz, R. F. A, Kryger, P., Allsopp, M. H. (1996) Competition for royalty in bees. Nature $\mathbf{3 8 4}, 31$

Neumann, P., Moritz, R. F. A. (2000) Testing genetic variance hypotheses for the evolution of polyandry in the honeybee (Apis mellifera L.). Insect. Soc. 47, 271-279

Osman, A., Alsomait, H., Seshadri, S., El-Toukhy, T., Khalaf, Y. (2015) The effect of sperm DNA fragmentation on live birth rate after IVF or ICSI: a systematic review and meta-analysis. Reprod. BioMed. Online 30, 120-127

Palmer, K. A., Oldroyd, B. P. (2000) Evolution of multiple mating in the genus Apis. Apidologie 31, 235-248

Poland, V, Eubel, H, King, M, Solheim, C, Millar, A. H., Baer, B. (2011) Stored sperm differs from ejaculated sperm by proteome alterations associated with energy metabolism in the honeybee Apis mellifera. Mol. Ecol. 20, 2643-2654

Ruttner, F. (1956) Zur Frage der Spermaübertragung bei der Bienenkönigin. Insect. Soc. 3 , 351-359

Ruttner, F., Koeniger, G. (1971) Die Füllung der Spermatheka der Bienenkönigin: active Wanderung oder passiver Transport der Spermatozoen?. Z. Vgl. Physiol. 72, 411-422

Sammataro, D., Avitabile, A. (1998) The Beekeeper's Handbook. Comstock Publishing Associates

Simon, L., Emery, B. R., Carrell, D. T. (2017) Review: Diagnosis and impact of sperm DNA alterations in assisted reproduction. Best Pract. Res. Clin. Obstet. Gynaecol. 44, 38-56

Sokal, R. R., Rohlf, F. J. (1981) Biometry. W. H. Freeman and Company, New York

Strassmann, J. E. (2001) The rarity of multiple mating by females in the social hymenoptera. Insect. Soc. 48, 1-13

Tryasko, W. W. (1951) Priznaki osemennosti pcelich matok. Pčelovodstvo 11, 25-31

Wegener, J., Zschörnig, K., Onischke, K., Fuchs, B., Schiller, J., Müller, K. (2013) Conservation of honey bee (Apis mellifera) sperm phospholipids during storage in the bee queen-a TLC/ MALDI-TOF MS Study. Exp. Gerontol. 48, 213-222

Winston, M. L. (1991) The Biology of the Honey Bee. Cambridge: Harvard University Press

Woyke, J. (1962) The hatchability of "lethal" eggs in a two sexallele fraternity of honeybees. J. Apic. Res. 1, 6-13

Woyke, J. (1963a) Contribution of successive drones to the insemination of a queen. Proceedings, Comp. Text. of Lect. of XIX Congress of Apimondia, 715-718

Woyke, J. (1963b) Drone larvae from fertilized eggs of the honeybee. J. Apic. Res. 2, 19-24

Woyke, J. (1963c) What happens to diploid drone larvae in a honeybee colony. J. Apic. Res. 2, 73-76

Woyke, J. (1976) Brood-rearing efficiency and absconding in Indian honeybees. J. Apic. Res. 15, 133-143 